\title{
Original Research \\ Validation of the parental knowledge and attitude towards antibiotic usage and resistance among children in Tetovo, the Republic of Macedonia
}

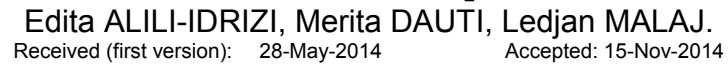

\begin{abstract}
${ }^{*}$
Objective: This study sought to explore the knowledge and attitudes of parents on the use of antibiotics among children that could serve as baseline data and provide further insight in planning and developing strategies for local health education purposes.

Methods: A cross-sectional survey involving 500 parents who attended community pharmacies in Tetovo, Republic of Macedonia, was conducted using a self-administered questionnaire from October 2013 to January 2014. The questionnaire included demographics, knowledge and attitude statements of parents towards antibiotics. The data collected were analyzed using SPSS program, version 19.0. Descriptive statistics was used to summarize the data. In all statistical analyses, a p-value of $<0.05$ was considered statistically significant.

Results: Nearly $40 \%$ of the parents demonstrated a moderate level of knowledge. The highest correct response in the knowledge part was the awareness of parents in using antibiotics to treat a bacterial infection $(61.2 \%)$. However, most of the parents did not know that antibiotics cannot cure viral infections (59.6\%). About $48.2 \%$ of the parents were aware of the antibiotic resistance as $\mathrm{s}$ result of the overuse. Concerning attitudes, $60.8 \%$ reported keeping any leftover antibiotics, $77.0 \%$ agreed that taking antibiotics when having cold symptoms could help their children recover faster, while, $74.6 \%$ wrongly agreed with the statement of appropriate use of antibiotics for prophylaxis' measure.

Conclusions: This study has documented the main areas that merit attention when parental knowledge on antibiotic use for their children is the concern, reflecting in some inappropriate attitudes as well. The findings highlight the need to devise effective interventions to decrease misconceptions regarding antibiotic use and to increase parents' awareness for the risks of inappropriate use of antibiotics in children specifically and in the community at large.
\end{abstract}

Keywords: Anti-Bacterial Agents; Drug Resistance, Bacterial; Health Knowledge, Attitudes, Practice; Parents; Macedonia (Republic)

\footnotetext{
"Edita ALILI-IDRIZI. B.Pharm, MSc. Assistant. Department of Pharmacy, Faculty of Medicine, State University of Tetovo. Tetovo (Republic of Macedonia). edita.alili79@gmail.com

Merita DAUTI. B.Pharm, MSc. Assistant. Department of Pharmacy, Faculty of Medicine, State University of Tetovo. Tetovo (Republic of Macedonia). merita_leka@yahoo.com Ledjan MALAJ. B.Pharm, MSc, PhD. Professor. Faculty of Pharmacy, University of Medicine, Tirana. Tirana (Albania). ledjan.malaj@gmail.com
}

\section{INTRODUCTION}

Antibiotics are the most frequently prescribed and misused drugs and there are reported concerns about the continuous indiscriminate and excessive use of antibiotics leading to the emergence and spread of antibiotic-resistant organisms. ${ }^{1,2}$ The use of antimicrobial agents, especially antibiotics, has become a routine practice for the treatment of pediatric illnesses. ${ }^{3,4}$ A substantial portion of prescribed antibiotics is considered nonessential, and such prescribing may be due to reasons related to: patients, parents or guardians, or the physicians. ${ }^{5-7}$ Studies from American, Asian and European countries indicate that between $22 \%$ and $70 \%$ of parents have misconceptions about the appropriate applications and efficacy of antibiotics ${ }^{8,9}$ and often use them without a prescription. ${ }^{10-12}$ It is estimated that more than $50 \%$ of antibiotics worldwide are purchased privately without a prescription, from pharmacies or street vendors in the informal sector. ${ }^{13}$ Haung et al. revealed that while most antibiotics about $66.66 \%$ is given to children according to prescriptions, the rest of antibiotics are given without prescriptions. ${ }^{14}$ Selfmedication has also been noted in the United States of America and Europe, particularly for colds and upper respiratory tract symptoms, which are selflimiting and mostly caused by viruses. ${ }^{15,16}$ Therefore, several studies have discussed the causes associated with antibiotic overuse. These include attitudes, beliefs, knowledge of antibiotic use $^{17-19}$, behaviors ${ }^{20,21}$, patients' perceptions regarding patient-doctor interaction, patient satisfaction, and patients' experience with antibiotics. $^{19-22}$ The rationale for educating the public is that knowledge about antibiotic treatment and awareness of antibiotic resistance are thought to influence patient and parent demand for antibiotic prescribing. ${ }^{23}$ Bajcetic and Jovanovic observed lack of knowledge and skill in administering antibiotics among children. The authors indicated that parents lack essential knowledge to deal with antibiotics they give to their children. ${ }^{24}$ Because of wide crossnational differences in antibiotic use ${ }^{25}$, tailoring of educational interventions requires determination of the needs of the audience in each country. Thus, this study sought to explore the knowledge and attitudes of parents on the use of antibiotics among children that could serve as baseline data and provide further insight in planning and developing strategies for local health education purposes. 


\section{METHODS}

\section{Study design}

A cross-sectional survey was conducted from October 2013 to January 2014 among 500 parents who attended community pharmacies in Tetovo, an urban city in the north-western part of the Republic of Macedonia. The community pharmacies were randomly selected, in order to obtain an unbiased sample of the parents regarding age, gender and level of education. In total six community pharmacies were randomly selected with an alpha $5 \%$ and a power of $80 \%$. The sample size of 500 parents was calculated to give a $95 \%$ confidence level and $5 \%$ margin of error assuming that $50 \%$ of parents answered each question correctly. The parents were recruited consecutively. All parents presenting a prescription for the treatment of their child with antibiotics were eligible for the study. The inclusion criteria were: (1) Parents aged 18 years and over; (2) Parents of children younger than 14 years; (3) not working as health care provider (4) aware of the term 'Antibiotics'. In order to increase compliance, pharmacists in the randomly selected community pharmacies were personally informed by the researcher about the study and its importance. They were asked to distribute the questionnaires to the parents, collect and give them back to the researcher. Verbal consent was obtained from all parents enrolled in the study before administering the questionnaire. No personal identifiers were included in the form.

\section{Questionnaire development and grading}

This self-administered questionnaire was developed by reviewing relevant literature and questionnaires used previously for the same manner. ${ }^{26-31}$ In the first part of the questionnaire, information about the parents' sex, age, education level, number of children aged one week and 14 years and experience of antibiotic use was noted. The second part consisted of nine knowledge statements covering aspects including the role of antibiotics, identification of antibiotics, dangers of using antibiotics (allergy reaction) and antibiotic efficacy. Parents were asked to respond with either "Yes," "No" or "Not Sure." The third part contained ten attitude statements including patient-doctor relationship. Parents were asked to answer the statements according to a 5-point Likert scale ranging from "Strongly Disagree" to "Strongly Agree." To simplify the analysis, we classified those who answered "Strongly Disagree" and "Disagree" like having disagreed and those who answered "Strongly Agree" and "Agree" as having agreed. The option "Disagree" for statements 1-6 and "Agree" for statements seven to 10 in the attitude domain indicated a positive attitude.

The questionnaire was designed in three language versions: English, Albanian and Macedonian. A pilot study was conducted with 30 subjects randomly selected. From the pilot study, respondents easily answered the questionnaire provided.

\begin{tabular}{|c|c|c|}
\hline Characteristics & $\begin{array}{l}\text { Total frequency } \\
(\mathrm{N})\end{array}$ & Percent \\
\hline $\begin{array}{l}18-30 \\
31-40 \\
41-50 \\
51-60 \\
61-70\end{array}$ & $\begin{array}{l}133 \\
156 \\
140 \\
56 \\
15\end{array}$ & $\begin{array}{c}26.6 \\
31.2 \\
28.0 \\
11.2 \\
3.0\end{array}$ \\
\hline $\begin{array}{r}\text { Male } \\
\text { Female } \\
\end{array}$ & $\begin{array}{l}277 \\
223 \\
\end{array}$ & $\begin{array}{l}55.4 \\
44.6 \\
\end{array}$ \\
\hline $\begin{array}{r}\text { Educational Status } \\
\text { Primary or lower } \\
\text { Secondary } \\
\text { University }\end{array}$ & $\begin{array}{c}4 \\
179 \\
317\end{array}$ & $\begin{array}{c}0.8 \\
35.8 \\
63.4\end{array}$ \\
\hline $\begin{array}{l}\text { Recent antibiotic use } \\
\text { Within the last months } \\
\text { More than } 12 \text { months ago }\end{array}$ & $\begin{array}{c}433 \\
67\end{array}$ & $\begin{array}{l}86.6 \\
13.4\end{array}$ \\
\hline
\end{tabular}

\section{Statistical analysis}

In the second part assessing the antibiotic knowledge of the parents, 1 mark was awarded for each correct answer, while each wrong or unsure response was marked 0 , with a maximum obtainable correct score of 9 . An arbitrary scoring was used to assess the level of knowledge based on the answers given. Three levels of categorizing the total knowledge were used indicating poor (0-3) mark 1, moderate (4-6) mark two and good (7-9) mark 3 . In the third part positive attitude were given 1 mark, while negative attitude or "Not Sure" were scored with 0 . Unsure responses were included to discourage guessing and scored as incorrect. The data collected were analyzed using Statistical Package for Social Sciences program (SPSS), version 19.0. Descriptive statistics was used to summarize the data about demographic characteristics, knowledge and attitudes toward antibiotic usage. Chi-square and Fisher exact tests were used to test for significant association between demographic characteristics such as sex of parents, age, education, number of children in the household and reported recent antibiotic use with knowledge and attitude. In all statistical analyses, a p-value of $<0.05$ was considered statistically significant.

\section{RESULTS}

\section{Parent's demographic characteristics}

A total of 500 parents from various ethnicities were enrolled in this study. No parent refused to take part in this questionnaire study. More fathers (55.4\%) responded than mothers. Parent's personal characteristics are summarized in Table 1. Almost an equal distribution of parents for age groups between 18-50 years old was revealed. The median of age was 45.5 years (range:18-70). The majority of parents have completed university $(63.4 \%)$. From the results obtained, $86.6 \%$ of parents reported using antibiotics within the last months.

\section{Parent's knowledge of antibiotics}

About the level of knowledge, $29.4 \%$ of parents were at the poor level of overall scores of knowledge, $53.0 \%$ had a moderate level of knowledge, and $17.6 \%$ had good knowledge. 


\begin{tabular}{|c|c|c|c|c|c|}
\hline \multirow{2}{*}{ Characteristics } & \multirow{2}{*}{$\begin{array}{c}\text { Frequency } \\
\mathrm{N}(\%)\end{array}$} & \multicolumn{3}{|c|}{ Level of knowledge $n(\%)$} & \multirow{2}{*}{$\mathrm{p}$ Value } \\
\hline & & Poor & Moderate & Good & \\
\hline Age & & & & & $2.155 \mathrm{E}-4^{*}$ \\
\hline $18-30$ & $133(26.6)$ & $33(6.6)$ & $74(14.8 \%)$ & $26(5.2 \%)$ & \\
\hline $31-40$ & $156(31.2)$ & $32(6.4)$ & $96(19.2 \%)$ & $28(5.6 \%)$ & \\
\hline $41-50$ & $140(28.0)$ & $44(8.8)$ & $72(14.4 \%)$ & $24(4.8 \%)$ & \\
\hline $51-60$ & $56(11.2)$ & $28(5.6)$ & $20(4.0 \%)$ & $8(1.6 \%)$ & \\
\hline $61-70$ & $15(3.0)$ & $10(2.0)$ & $3(0.6 \%)$ & $2(0.4)$ & \\
\hline Sex & & & & & 0.507 \\
\hline Male & $277(55.4)$ & $85(17.0)$ & $150(30.0 \%)$ & $42(8.4 \%)$ & \\
\hline Female & $223(44.6)$ & $62(12.4)$ & $115(23.0 \%)$ & $46(9.2 \%)$ & \\
\hline Educational Status & & & & & $1.151 \mathrm{E}-44^{*}$ \\
\hline Primary or lower & $4(0.8)$ & $4(0.8)$ & $0(0.0)$ & $0(0.0)$ & \\
\hline Secondary & $179(35.8)$ & $120(24.0)$ & $53(10.6 \%)$ & $6(1.2 \%)$ & \\
\hline University & 317 (63.4) & $23(4.6)$ & $212(42.4 \%)$ & $82(16.4 \%)$ & \\
\hline Recent antibiotic use & & & & & 0.877 \\
\hline Within the last months & $433(86.6)$ & $129(29.8)$ & $171(39.5)$ & $133(30.7)$ & \\
\hline More than 12 months ago & $67(13.4)$ & $18(26.9)$ & $27(40.3)$ & $22(32.8)$ & \\
\hline
\end{tabular}

The difference in knowledge level was statistically significant between age groups and levels of education (Table 2). Poor level of knowledge was found in the generation between the ages of 41-50 years $(8.8 \%$ versus others $<6.6 \%)$, and in a secondary educational level $(24.0 \%$ versus others $<4.6 \%$ ).

From the evaluation of the knowledge about the role of antibiotics (Table 3), it was found that the highest correct response in the knowledge part was the awareness of parents in using antibiotics to treat a bacterial infection (61.2\%). However, most of the parents did not know that antibiotics cannot cure viral infections $(59.6 \%)$, followed by $44 \%$ of the parents who wrongly thought that taking antibiotics when their children are having a cold could help them recover faster. As for the identification of antibiotics, $65.2 \%$ of the parents could make a difference between antibiotics and pain relievers such as paracetamol and $82.4 \%$ could correctly identify penicillin as an antibiotic. On the other hand, $69.6 \%$ of the parents seemed to be aware that antibiotics may cause allergic reactions to their children. As for the section of antibiotic effectiveness, a high percentage of parents $(60.1 \%)$ were more knowledgeable about the importance of completing the full treatment course of antibiotics. On the other hand, only $7.4 \%$ disagreed with the statement that reducing the prescribed dose of antibiotics could be healthier for their children. About $57.6 \%$ believed that the effectiveness of antibiotics is related to the cost and novelty.

\begin{tabular}{|c|c|c|c|c|c|c|c|}
\hline \multirow[b]{2}{*}{ Statement } & \multirow[b]{2}{*}{ Correct answer } & \multirow[b]{2}{*}{ Incorrect answer } & \multirow[b]{2}{*}{ Unsure } & \multicolumn{4}{|c|}{$\mathrm{p}$ value (chi-square test/ Fisher Exact test) } \\
\hline & & & & Age & Gender & Education & $\begin{array}{l}\text { Recent } \\
\text { antibiotic } \\
\text { use }\end{array}$ \\
\hline \multicolumn{8}{|c|}{ Role of Antibiotics } \\
\hline $\begin{array}{l}\text { Antibiotics can treat bacterial } \\
\text { infections }\end{array}$ & $306(61.2 \%)$ & $17 \quad(3.4 \%)$ & $177(35.4 \%)$ & 0.498 & 0.731 & $5.369 \mathrm{E}-7^{*}$ & 0.816 \\
\hline $\begin{array}{l}\text { Antibiotics can cure viral } \\
\text { infections }\end{array}$ & $121(24.2 \%)$ & $298(59.6 \%)$ & $81(16.2 \%)$ & 0.260 & 0.326 & $4.752 \mathrm{E}-14^{*}$ & 0.559 \\
\hline $\begin{array}{l}\text { Antibiotics must be taken } \\
\text { once a child has a cold }\end{array}$ & $198(39.6 \%)$ & $220(44.0 \%)$ & $82(16.4 \%)$ & 0.463 & 0.971 & $1.332 \mathrm{E}-14^{*}$ & 0.938 \\
\hline \multicolumn{8}{|c|}{ Identification of Antibiotics } \\
\hline $\begin{array}{l}\text { Antibiotics are the same as } \\
\text { medications used to relieve } \\
\text { pain and fever such as } \\
\text { paracetamol }\end{array}$ & $326(65.2 \%)$ & $64(12.8 \%)$ & $110(22.0 \%)$ & 0.874 & 0.332 & $1.906 \mathrm{E}-11^{*}$ & 0.838 \\
\hline Penicillin is an antibiotic & $412(82.4 \%)$ & $(0 \%)$ & $88(17.6 \%)$ & $0.007^{*}$ & 0.480 & 1.394E-15* & 0.730 \\
\hline \multicolumn{8}{|c|}{ Dangers of Antibiotics } \\
\hline $\begin{array}{l}\text { Children can be allergic to } \\
\text { antibiotics }\end{array}$ & $348(69.6 \%)$ & $61(12.2 \%)$ & $91(18.2 \%)$ & $0.034^{*}$ & 0.155 & $2.237 \mathrm{E}-4^{*}$ & 0.469 \\
\hline \multicolumn{8}{|c|}{ Effectiveness of Antibiotics } \\
\hline $\begin{array}{l}\text { The effectiveness of } \\
\text { treatment is reduced if a full } \\
\text { course of antibiotic is not } \\
\text { completed }\end{array}$ & $300(60.1 \%)$ & $118(23.6 \%)$ & $82(16.4 \%)$ & 0.115 & 0.174 & $6.661 \mathrm{E}-14^{*}$ & 0.565 \\
\hline $\begin{array}{l}\text { Taking fewer antibiotics then } \\
\text { prescribed is healthier than } \\
\text { taking the full course } \\
\text { prescribed }\end{array}$ & $310(62.0 \%)$ & $37 \quad(7.4 \%)$ & $153(30.6 \%)$ & 0.072 & 0.611 & $3.950 \mathrm{E}-8^{*}$ & 0.257 \\
\hline $\begin{array}{l}\text { Is the efficacy better if the } \\
\text { antibiotics are newer and } \\
\text { more costly }\end{array}$ & $145(29.0 \%)$ & $288(57.6 \%)$ & 67 (13.4\%) & 0.379 & 0.186 & $0.004^{*}$ & 0.206 \\
\hline
\end{tabular}




\begin{tabular}{|c|c|c|c|c|c|c|c|}
\hline \multirow[b]{2}{*}{ Statement } & \multirow[b]{2}{*}{ Disagree } & \multirow[b]{2}{*}{$\begin{array}{l}\text { Neither } \\
\text { agree nor } \\
\text { disagree }\end{array}$} & \multirow[b]{2}{*}{ Agree } & \multicolumn{4}{|c|}{$\mathrm{p}$ value (chi-square test/ Fisher Exact test) } \\
\hline & & & & Age & Gender & Education & $\begin{array}{l}\text { Recent } \\
\text { antibiotic } \\
\text { use }\end{array}$ \\
\hline $\begin{array}{l}\text { Leftover antibiotics are good } \\
\text { to keep at home in case I } \\
\text { might be needed it for my } \\
\text { child later on. }\end{array}$ & $\begin{array}{c}177 \\
(35.4 \%)\end{array}$ & $\begin{array}{c}19 \\
(3.8 \%)\end{array}$ & $\begin{array}{c}304 \\
(60.8 \%)\end{array}$ & $0.015^{\star}$ & 0.117 & 1.396E-22* & 0.772 \\
\hline $\begin{array}{l}\text { It is good to be able to get } \\
\text { antibiotics for my child from } \\
\text { siblings, relatives or friends } \\
\text { without having to see a } \\
\text { doctor. }\end{array}$ & $\begin{array}{c}214 \\
(42.8 \%)\end{array}$ & $\begin{array}{c}48 \\
(9.6 \%)\end{array}$ & $\begin{array}{c}238 \\
(47.6 \%)\end{array}$ & $0.013^{*}$ & 0.583 & $3.786 \mathrm{E}-22^{*}$ & 0.737 \\
\hline $\begin{array}{l}\text { It would be good to be able } \\
\text { to buy antibiotics over-the- } \\
\text { counter at the pharmacy. }\end{array}$ & $\begin{array}{c}240 \\
(48.0 \%)\end{array}$ & $\begin{array}{c}81 \\
(16.2 \%)\end{array}$ & $\begin{array}{c}179 \\
(35.8 \%)\end{array}$ & 0.173 & $0.006^{*}$ & $3.333 \mathrm{E}-21^{*}$ & 0.230 \\
\hline $\begin{array}{l}\text { It is appropriate to use } \\
\text { antibiotics when my child } \\
\text { has a sore throat because } \\
\text { otherwise he/she might } \\
\text { catch something more } \\
\text { serious. }\end{array}$ & $\begin{array}{c}71 \\
(14.2 \%)\end{array}$ & $\begin{array}{c}56 \\
(11.2 \%)\end{array}$ & $\begin{array}{c}373 \\
(74.6 \%)\end{array}$ & $0.005^{*}$ & $0.009^{*}$ & 1.251E-29* & 0.205 \\
\hline $\begin{array}{l}\text { Antibiotics speed } \\
\text { recovery from a cold }\end{array}$ & $\begin{array}{c}95 \\
(19.0 \%)\end{array}$ & $\begin{array}{c}20 \\
(4.0 \%)\end{array}$ & $\begin{array}{c}385 \\
(77.0 \%)\end{array}$ & $2.664 \mathrm{E}-6^{*}$ & $3.428 \mathrm{E}-4^{*}$ & $4.383 \mathrm{E}-24^{*}$ & 0.248 \\
\hline $\begin{array}{l}\text { usually stop giving } \\
\text { antibiotics to my child when } \\
\text { he/she starts feeling better }\end{array}$ & $\begin{array}{c}303 \\
(60.6 \%)\end{array}$ & $\begin{array}{c}42 \\
(8.4 \%)\end{array}$ & $\begin{array}{c}155 \\
(31.0 \%)\end{array}$ & $2.791 \mathrm{E}-5^{*}$ & $9.368 \mathrm{E}-9^{*}$ & $9.729 \mathrm{E}-17^{*}$ & 0.201 \\
\hline $\begin{array}{l}\text { I will stop giving my child an } \\
\text { antibiotic if he/she has skin } \\
\text { reaction or gets side-effects }\end{array}$ & $\begin{array}{c}0 \\
(0.0 \%)\end{array}$ & $\begin{array}{c}59 \\
(11.8 \%)\end{array}$ & $\begin{array}{c}441 \\
(88.2 \%)\end{array}$ & $0.001^{*}$ & $0.050^{*}$ & $1.843 \mathrm{E}-9^{*}$ & 0.237 \\
\hline $\begin{array}{l}\text { I usually will look at the } \\
\text { expiry date of antibiotics } \\
\text { before giving it to my child }\end{array}$ & $\begin{array}{c}4 \\
(0.8 \%)\end{array}$ & $\begin{array}{c}219 \\
(43.8 \%)\end{array}$ & $\begin{array}{c}277 \\
(55.4 \%)\end{array}$ & $3.749 \mathrm{E}-11^{*}$ & $0.044^{*}$ & $3.481 \mathrm{E}-17^{*}$ & 0.055 \\
\hline $\begin{array}{l}\text { Doctors often take time to } \\
\text { consider carefully whether } \\
\text { my child needs to be } \\
\text { prescribed antibiotics or not }\end{array}$ & $\begin{array}{c}106 \\
(21.2 \%)\end{array}$ & $\begin{array}{c}101 \\
(20.2 \%)\end{array}$ & $\begin{array}{c}293 \\
(58.6 \%)\end{array}$ & $0.037^{*}$ & $0.003^{*}$ & $4.119 \mathrm{E}-4^{*}$ & 0.171 \\
\hline $\begin{array}{l}\text { Doctors often take time to } \\
\text { inform parents how } \\
\text { antibiotics should be used } \\
\text { for their children }\end{array}$ & $\begin{array}{c}95 \\
(19.0 \%)\end{array}$ & $\begin{array}{c}106 \\
(21.2 \%)\end{array}$ & $\begin{array}{c}299 \\
(59.8 \%)\end{array}$ & $0.007^{*}$ & $0.016^{*}$ & $9.186 \mathrm{E}-5^{*}$ & 0.613 \\
\hline
\end{tabular}

Education was a significant predictor for all the statements assessed in the knowledge part, while age appeared to be significant mainly for the dangers of antibiotics.

\section{Parent's attitudes towards antibiotic use}

The attitude score ranged from zero to 10 points. The percentages of inappropriate responses for ten attitude statements are summarized in Table 4 . In our study, $60.8 \%$ of parents reported keeping leftover antibiotic if their child may be needed it later. Almost an equal distribution of parents reported their agreement/disagreement for sharing antibiotics for their children with siblings, relatives or friends. Meanwhile, $77.0 \%$ of the parents agreed that taking antibiotics when the child is having a cold could help them recover faster, while, $74.6 \%$ of the parents wrongly agreed with the statement of proper use of antibiotics for prophylaxis' measure. Although, $48 \%$ of the parents seemed to be aware that antibiotics cannot be purchased as over-thecounter, it was noted that almost $36 \%$ prefer the possibility to do so. About $31.0 \%$ stopped giving antibiotics to their children when symptoms improved. A small percentage of parents demonstrated little caution when consuming antibiotics. In particular, a high percentage of parents $(88.2 \%)$ agreed to stop giving a child an antibiotic if skin reaction or any side-effects appears, while, $0.8 \%$ did not check expiry dates.

Information and trust were evaluated in two statements on the topic 'patient-doctor relationship'. Most of the parents $(58.6 \%)$ reported trusting the consideration of doctors whether to prescribe an antibiotic for their children. In addition, $59.8 \%$ of them declared doctor often take time to tell them about the usage of antibiotics for their children.

\section{DISCUSSION}

The aim of this questionnaire was to assess parental knowledge and attitudes on antibiotic use for their children. Thirteen percent of parents said that they did not use antibiotics in the past year for their children, which is higher than the percentage $(3.3 \%)$ noted in the study done in Riyadh, Saudi Arabia. ${ }^{32}$ The findings have shown confusion among parents about the effectiveness of antibiotics for bacterial or viral infections. Among 500 parents involved in the study, almost $60 \%$ believe that antibiotic is a proper treatment for viral infections, which is comparable with the proportion of parents $(68.6 \%)$ in Riyadh, Saudi Arabia. ${ }^{32}$ On the other hand, the percentage of parents who knew that 
antibiotics are effective for bacterial infection $(61.2 \%)$ was much higher than the percentage found in Al-Ain City, United Arab Emirates. ${ }^{33}$ In the present study, $44 \%$ of the parents were found to believe that antibiotics must be taken for common cold, which is lower than the percentage $(68 \%)$ found in Hulu Langat district, Malaysia. ${ }^{18}$ Frequent prescribing of antibiotics for viral respiratory infections, which mainly are self-limiting, has influenced parental misconceptions and confusion regarding the indications of antibiotics use. Hence, indications for use of antibiotics are to be suggested among main issues in parental education activities.

In an effort to clarify if the parents were able to identify antibiotics, it was found that most of the parents replied correctly. Overall, most of the parents $(69.6 \%)$ were aware with the risk of antibiotic use such as an allergic reaction. Similarly, in a questionnaire conducted in Amman, $\operatorname{Jordan}^{34}$, it is showed that most of the sample $(65 \%)$ were aware that their children may develop an allergic reaction to antibiotic and that may cause death. Most of the respondents $(60.1 \%)$ had correctly agreed that the effectiveness of treatment could be reduced without completion of the full course of antibiotics that is $1.9 \%$ less as compared with $62.0 \%$ who know the need to take the full course prescribed. A comparable proportion of parents who agreed that overuse and inappropriate use of antibiotics reduce efficacy was noted in the study done in Riyadh, Saudi Arabia. ${ }^{35}$ Most of the parents $(57.6 \%)$ incorrectly consider that newer and more costly antibiotics give better effectiveness, as a reason more towards inappropriate use of antibiotics.

Parents in our study had substantial misunderstandings that may contribute greatly to inappropriate antibiotic use. A relevant concern is that most of the parents $(60.8 \%)$ in the present study agreed to keep a left-over antibiotic at home, which might be another indicator of antibiotic misuse. This proportion is much lower in Patras, Greece, where very few respondents (7.3\%) declared they keep left-over antibiotics for future use. ${ }^{19}$ In particular, more parents from our study were expecting antibiotics to speed up the recovery of their children from the common cold $(77 \%)$. The need for a quick recovery in order to return to child care could further contribute to the parental misuse of antibiotics in communities that depend on institutional rather than family child care. ${ }^{36}$ In a study done in Amman, Jordan ${ }^{34}$ more than half of respondents $(52.5 \%)$ that are $5 \%$ more as compared to $47.6 \%$ of the parents from our study reported using antibiotics between siblings.

Differences in implementing drug regulations that affect the availability of antibiotics in different countries can play an important role in misconceptions about antibiotics. ${ }^{37}$ Increased availability of over the counter antibiotics at the pharmacy despite the fact that this is against the law, is an important component contributing to selfmedicating children with antibiotics. In our study, $48.0 \%$ of parents preferred the possibility of purchasing antibiotics over the counter. This gray area of pharmacy practice deserves further investigations to know the relative importance of over-the-counter sales. In our study, $31.0 \%$ of parents admitted that their child did not finish the entire course of antibiotics given. A lower proportion $(26 \%)$ of parents with the same incorrect knowledge was noted in the study done in Malaysia. ${ }^{18}$

There should be made efforts of improving this practice that increases the risk of relapse and the development of resistant pathogens. In contrast, to those misconceptions, a high proportion (88.2\%) of parents in this study reported stopping treatment earlier if skin reaction or side-effects appear, which in a way it can be an indicator that parents had enough knowledge about the risks of using antibiotics. Also, the trust and the confidence in doctors are evident. More than half of parents $(58.6 \%)$ demonstrated trust in the doctor, for the decision of antibiotic prescribing or not and $59.8 \%$ of them were satisfied with the information given by the doctor about the usage of antibiotics. This good patient-doctor relationship should be emphasized in increasing mutual communications because findings show the important role of doctors in the appropriate use of antibiotics among children.

\section{Limitations}

Parent's data were collected through a selfadministered questionnaire. This methodology was preferred more than the face-to-face or telephone interviews for the chance of avoiding interviewer influence in the parents' response and as well for the likelihood interviewees to respond in accordance with what is believed to be the expected answer. Additionally, we avoided the impractical training of many interviewers and as well, we aimed to exclude the impact of the variability among the interviewers. On the other hand, self-administered questionnaire increases the precision of responses obtained since each parent received the same formulated set of statements. However, some limitations in this study are to be mentioned. The main limitation of this study is that the data provided is of local interest and that participants were parents of children who had had a prescription for antibiotics, so they are not comparable with a population-based sample. Also, there were an unexpectedly high proportion of participants with higher educational qualification compared to other groups which might have had an impact on the study findings. Excluding all the parents who had never heard about antibiotics might result in missing information regarding this category of parents. Similarly to all self-administered public surveys, the results revealed in this questionnaire study were dependent on the honesty and understanding of the parents.

Despite its limitations this study has identified significant parental knowledge and attitude deficiencies and misconceptions, resulting in an irrational use of antibiotics in Tetovo, the Republic of Macedonia. 


\section{CONCLUSIONS}

In conclusion, this study has documented the main areas that merit attention when parental knowledge on antibiotic use for their children is the concern, reflecting in some inappropriate attitudes as well. The findings highlight the need to devise effective interventions to decrease misconceptions regarding antibiotic use and to increase parents' awareness for the risks of inappropriate use of antibiotics in children specifically and in the community at large. These strategies should include well-planned, organized and structured educational programs that focus on the basic concepts of antibiotics, appropriate use and the consequences of misuse and as well the importance for discontinuation of using leftover antibiotics. In addition, there should be included information about the complications associated with antibiotic resistance and the importance of maintaining the current trust in the doctors' decision for prescribing or not antibiotics. Reinforcement of the existing national regulation is essential to restrict antibiotics as prescription-only medicines.

Change, however, does not come easily; multifaceted approaches are needed to tackle the problem of improving rational use of antibiotics.

\section{CONFLICT OF INTEREST}

None declared

Funding: This research received no specific grant from any funding agency in the public, commercial or not-for-profit sector.

\section{VALIDACIÓN DEL CONOCIMIENTO Y ACTITUDES PARENTERALES SOBRE USO DE ANTIBIÓTICOS Y RESISTENCIAS EN NIÑOS DE TETOVO, REPUBLICA DE MACEDONIA}

\section{RESUMEN}

Objetivo: Este estudio intentó explorar el conocimiento y actitudes de padres sobre el uso de antibióticos en niños para servir como punto de partida y proporcionar futuro conocimiento para planear y desarrollar estrategias de educación local de salud.

\section{Métodos:}

Se realizó un estudio transversal que incluyo a 500 pacientes que visitaron farmacias comunitarias en Tetovo, República de Macedonia mediante el uso de un cuestionario auto-administrado entre octubre 2013 y enero 2014. El cuestionario incluía datos demográficos y afirmaciones sobre conocimiento y actitud de los padres hacia los antibióticos. Los datos recogidos se analizaron usando el programa SPSS versión 19.0. Se usó estadística descriptiva para resumir los datos. En todos los análisis estadísticos se consideró estadísticamente significativo un valor de $\mathrm{p}<0,05$.

Resultados: Casi el $40 \%$ de los padres demostraron tener un nivel moderado de conocimiento. La respuesta correcta más frecuente en la parte de conocimiento era la consciencia de los padres de que los antibióticos se usan para tratar una infección bacteriana $(61,2 \%)$. Sin embargo, la mayoría de los padres no sabían que los antibióticos no curan infecciones víricas $(59,6 \%)$. Alrededor del 48,2\% de los padres sabían que las resistencias a los antibióticos resultan de su sobreutilización. En relación a las actitudes, el 60,8\% comunicó guardar los restos de los antibióticos, el 77,0\% aceptó que tomar antibióticos cuando sus hijos tienen síntomas de resfriado puede ayudarles a recuperarse más rápidamente, mientras que el $74,6 \%$ estaba de acuerdo con la medida equivocada de usar antibióticos como medida profiláctica.

Conclusiones: Este estudio documentó las áreas principales que merecen atención en relación al conocimiento parenteral sobre uso de antibióticos para sus hijos, reflejando también algunas actitudes inadecuadas. Los hallazgos apuntan a la necesidad de diseñar intervenciones efectivas para disminuir los conceptos equivocados sobre el uso de antibióticos y aumentar el conocimiento de los padres sobre los riesgos del uso inapropiado de antibióticos en niños específicamente y en la comunidad en general.

Palabras clave: Antibacterianos; Resistencia Bacteriana a medicamentos; Conocimientos, Actitudes y Práctica en Salud; Padres; Macedonia (República)

1. McLellan NJ, Gray J. The rational use of antibiotics in bacterial infection. Curr Pediatr. 2001;11(6):438-444. doi:10.1054/cupe.2001.0234

2. Krivoy N, El-Ahal WA, Bar-Lavie Y, Haddad S. Antibiotic prescription and cost patterns in a general intensive care unit. Pharm Pract (Granada). 2007;5(2):67-73.

3. Ghai OP, Paul VK. Rational drug therapy in pediatric practice. Indian Pediatr. 1988;25(11):1095-1109.

4. Summers RS, Summers B. Drug prescribing in paediatrics. Ann Trop Paediatr. 1986;6(2):129-133

5. Dowell SF, Marcy SM, Phillips WR, Gerber MA, Schwartz B. Principles of judicious use of antimicrobial agents for pediatric upper respiratory tract infections. Pediatrics. 1998;101:163-165.

6. Nyquist AC, Gonzales R, Steiner JF, Sande MA. Antibiotic prescribing for children with colds, upper respiratory tract infections, and bronchitis. JAMA. 1998;279(11):875-877.

7. Nash DR, Harman J, Wald ER, Kelleher KJ. Antibiotic prescribing by primary care physicians for children with upper respiratory tract infections. Arch Pediatr Adolesc Med. 2002;156(11):1114-1119.

8. Belongia EA, Naimi TS, Gale CM, Besser RE. Antibiotic use and upper respiratory infections: a survey of knowledge, attitudes, and experience in Wisconsin and Minnesota. Prev Med. 2002;34(3):346-352. doi:10.1006/pmed.2001.0992

9. Huang SS, Rifas-Shiman SL, Kleinman K, Kotch J, Schiff N, Stille CJ, Steingard R, Finkelstein JA. Parental knowledge about antibiotic use: results of a cluster-randomized, multicommunity intervention. Pediatrics. 2007;119(4):698-706

10. Bi P, Tong SL, Parton KA. Family self-medication and antibiotics abuse for children and juveniles in a Chinese city. Soc Sci Med. 2000 May;50(10):1445-1450. doi:10.1016/S0277-9536(99)00304-4 
11. Larsson M, Kronvall G, Chuc NTK, Karlsson I, Lager F, Hanh HD, Tomson G, Falkenberg T. Antibiotic medication and bacterial resistance to antibiotics: a survey of children in a Vietnamese community. Trop Med Int Health. 2000;5(10):711-721. doi:10.1046/j.1365-3156.2000.00630.x

12. Okumura J, Wakai S, Umenai T. Drug utilisation and self-medication in rural communities in Vietnam. Soc Sci Med. 2002;54(12):1875-1886. doi:10.1016/S0277-9536(01)00155-1

13. Cars O, Nordberg P. Antibiotic resistance -The faceless threat. Int J Risk Saf Med. 2005;17:103-110.

14. Haung K, Hsieh Y, Hung C, Hsiao F. Off-lab antibiotic use in the pediatric population: a population-based study in Taiwan. J Food Drug Anal. 2012;20(3):597-602.

15. Grigoryan L, Burgerhof JG, Haaijer-Ruskamp FM, Degener JE, Deschepper R, Monnet DL Cunney R, Di Matteo A, Edelsein H, Valinteliene R, Alkerwi A, Scicluna E, Grzesiowski P, Bara AC, Tesar T, Cizman M, Campos J, Lundborg CS, Birkin J, SAR group. Is self-medication with antibiotics in Europe driven by prescribed use? J Antimicrob Chemother. 2007;59(1):152-156. doi:10.1093/jac/dkl457

16. Väänänen $\mathrm{MH}$, Pietilä K, Airaksinen M. Self-medication with antibiotics-does it really happen in Europe? Health Policy. 2006;77(2):166-171.doi:10.1016/j.healthpol.2005.07.001

17. Awad A, Eltayeb I, Matowe L, Thalib L. Self-medication with antibiotics and antimalarials in the community of Khartoum state, Sudan. J Pharm Pharm Sci. 2005;8(2):326-331.

18. Chan G, Tang SF. Parental knowledge, attitudes and antibiotic use for acute upper respiratory tract infection in children attending a primary healthcare clinic in Malaysia. Singapore Med J. 2006;47(4):266-270.

19. Mitsi G, Jelastopulu E, Basiaris H, Skoutelis A, Gogos C. Patterns of antibiotic use among adults and parents in the community: A questionnaire-based survey in a Greek urban population. Int J Antimicrob Agents. 2005;25(5):439-443.

20. Al-Azzam SI, Al-Husein BA, Alzoubi F, Masadeh MM, Al-Horani MA. Self-medication with antibiotics in jordanian population. Int J Occup Med Environ Health. 2007;20(4):373-380. doi: 10.2478/v10001-007-0038-9

21. Sarahroodi S, Arzi A, Sawalha AF, Ashtarinezhad A. Antibiotics self-medication among southern iranian university students. Int J Pharmacol. 2010;6:48-52. doi: 10.3923/ijp.2010.48.52

22. Crossley J, Eiser $\mathrm{C}$, Davies $\mathrm{H}$. Children and their parents assessing the doctor-patient interaction: a rating system for doctors' communication skills. Med Educ. 2005;39(8):820-828.

23. Vanden Eng J, Marcus R, Hadler JL Imhoff B, Vugia DJ, Cieslak PR, Zell E, Deneen V, McCombs KG, Zansky SM, Hawkins MA, Besser RE. Consumer attitudes and use of antibiotics. Emerg Infect Dis. 2003;9(9):1128-1135.

24. Bajčetić M, Jovanović I. Current aspects of rational antibiotic use in paediatrics. Paediatrics Today 2012;8(2):79-90 doi: 10.5457/p2005-114.43

25. Deschepper R, Grigoryan L, Lundborg CS, Hofstede G, Cohen J, Kelen GV, Deliens L, Haaijer-Ruskamp FM. Are cultural dimensions relevant for explaining cross-national differences in antibiotic use in Europe? BMC Health Serv Res. 2008;8:123. doi: 10.1186/1472-6963-8-123

26. Panagakou SG, Theodoridou MN, Papaevangelou V, Papastergiou P, Syrogiannopoulos GA, Goutziana GP, Hadjichristodoulou CS. Development and assessment of a questionnaire for a descriptive cross - sectional study concerning parents' knowledge, attitudes and practices in antibiotic use in Greece. BMC Infect Dis. 2009;9:52. doi: 10.1186/1471-2334-9-52

27. McNulty CA, Boyle P, Nichols T, Clappison P, Davey P. Don't wear me out--the public's knowledge of and attitude to antibiotic use. J Antimicrob Chemother. 2007;59(4):727-738.

28. Shehadeh M, Suaifan G, Darwish RM, Wazaify M, Zaru L, Alja'fari S. Knowledge, attitudes and behavior regarding antibiotics use and misuse among adults in the community of Jordan. A pilot study. Saudi Pharm J. 2012;20(2):125-133. doi: 10.1016/j.jsps.2011.11.005

29. Ling Oh A, Hassali MA, Al-Haddad MS, Syed Sulaiman SA, Shafie AA, Awaisu A. Public knowledge and attitudes towards antibiotic usage: a cross-sectional study among the general public in the state of Penang, Malaysia. J Infect Dev Ctries. 2011;5(5):338-347.

30. Alzoubi K, Al-Azzam S, Alhusban A, Mukattash T, Al-Zubaidy S, Alomari N, Khader Y. An audit on the knowledge, beliefs and attitudes about the uses and side-effects of antibiotics among outpatients attending 2 teaching hospitals in Jordan. East Mediterr Health J. 2013;19(5):478-484.

31. Lim KK, Teh CC. A Cross sectional study of public knowledge and attitude towards antibiotics in Putrajaya, Malaysia. South Med Rev. 2012;5(2):26-33.

32. Abobotain AH, Sheerah HA, Alotaibi FN, Joury AU, Mishiddi RM, Siddiqui AR, Saeed AB. Socoi-demographic determinants of antibiotic misuse in children. Saudi Med J. 2013;34(8):832-840.

33. Tenaiji A, Redha KA, Khatri F, Darmaki S, Hosani S, Neaimi MA, Khan A, Hashmey R. Knowledge Attitudes and Behavior Towards Antibiotic Use among Parents in Al-Ain City, United Arab Emirates. Int J Infect Dis. 2008;12:e434

34. Romman HA. Patterns of antibiotic use among children. Int J Med Med Sci. 2013;5(6):264-272. doi:10.5897/IJMMS12.050

35. Al-Dossari K. Parental knowledge, attitude and practice on antibiotic use for upper respiratory tract infections in children. Majmaah J Health Sci. 2013;1(1):39-51.

36. Bauchner H, Pelton SI, Klein JO. Parents, physicians, and antibiotic use. Pediatrics. 1999;103(2):395-401.

37. Cummings KC, Rosenberg J, Vugia DJ. Beliefs about appropriate antibacterial therapy, California. Emerg Infect Dis. 2005;11(7):1138-1141. 